Learning Leadership in a Changing World 
This page intentionally left blank 


\section{Learning Leadership in a Changing World}

Virtue and Effective Leadership in the 21st Century

Mark W. McCloskey

palgrave macmillan 


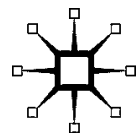

LEARNING LEADERSHIP IN A CHANGING WORLD

Copyright (C) Mark W. McCloskey, 2014.

Softcover reprint of the hardcover 1st edition 2014 978-1-137-47632-6

All rights reserved.

First published in 2014 by

PALGRAVE MACMILLAN ${ }^{\circledR}$

in the United States-a division of St. Martin's Press LLC,

175 Fifth Avenue, New York, NY 10010.

Where this book is distributed in the UK, Europe and the rest of the world, this is by Palgrave Macmillan, a division of Macmillan Publishers Limited, registered in England, company number 785998, of Houndmills, Basingstoke, Hampshire RG21 6XS.

Palgrave Macmillan is the global academic imprint of the above companies and has companies and representatives throughout the world.

Palgrave ${ }^{\circledR}$ and Macmillan ${ }^{\circledR}$ are registered trademarks in the United States, the United Kingdom, Europe and other countries.

ISBN 978-1-349-50195-3

ISBN 978-1-137-47637-1 (eBook)

DOI $10.1057 / 9781137476371$

Library of Congress Cataloging-in-Publication Data

McCloskey, Mark W.

Learning leadership in a changing world : virtue and effective leadership in the 21st century / Mark W. McCloskey.

pages $\mathrm{cm}$

Includes bibliographical references and index.

1. Leadership. I. Title.

HD57.7.M39527 2014

303.3' 4-dc23

2014023295

A catalogue record of the book is available from the British Library.

Design by Newgen Knowledge Works (P) Ltd., Chennai, India.

First edition: December 2014

$109876 \begin{array}{llllll}10 & 9 & 8 & 2 & 1\end{array}$ 
For Dawnelle, Kirsten, David, and Abby 
This page intentionally left blank 


\section{Contents}

List of Figures $\quad$ ix

Acknowledgments $\quad$ xi

Section I The Twenty-First-Century Leadership Context 1

1 Two Leadership Myths 3

2 The Mess: Say Hello to the New Normal 15

3 Myths Meet Mess: Old Normal Leaders in New Normal Times 25

Section II Next Practices and Ancient Assets 33

4 Next Practices: Part I 35

5 Next Practices: Part II 45

6 Next Practices: Part III 55

7 Ancient Assets for the Twenty-First Century 61

Section III The 4R Model of Leadership: Relationships 77

8 The 4R Model of Leadership 79

9 Dynamic Determination 89

10 Intellectual Flexibility 99

11 Courageous Character 109

12 Emotional Maturity 119

13 Collaborative Quotient 131 
Section IV The 4R Model: Roles

14 The Direction Setter Role

15 The Ambassador Role

16 The Learner Role

17 The Coach Role

18 The Steward Role

Section V The 4R Model: Responsibilities

201

19 Vision Casting

20 Strategy Making

21 Aligning

22 Encouraging

Section VI The 4R Model: Results

23 Results

24 Results and Relationships: Back to the Core 


\section{Figures}

6.1 Performance shifts and next practices

7.1 The diminishing value of charisma and technical-managerial competence

$\begin{array}{lll}7.2 & \text { Next practices and virtue assets } & 74\end{array}$

8.1 4R model overview $\quad 80$

$\begin{array}{ll}8.2 \text { Roles overview } & 82\end{array}$

8.3 Responsibilities overview 84

13.1 DICE + 1 \& virtue 139

14.1 Direction setter role 146

14.2 Missional integrity 152

15.1 Ambassador role 156

$\begin{array}{lll}16.1 & \text { Learner role } & 168\end{array}$

$\begin{array}{lll}17.1 & \text { Coach role } & 178\end{array}$

17.2 Missional development 182

18.1 Steward role 188

18.2 Today-tomorrow tensions 192

18.3 Us-others tensions 192

18.4 Continuity-change tensions 194

20.1 SWOT analysis framework 219

21.1 Renters and owners 231

21.2 Things you can and can't buy 235

24.1 Relationships and results 264 
This page intentionally left blank 


\section{Acknowledgments}

\footnotetext{
Twould like to offer special thanks to the Palgrave Macmillan team; to Casie Vogel for her encouragement and advice in the early stages 1 of this project, to Bradley Showalter for his advice and support, to Bhavana Nair for her work in guiding the production process, and to Smitha Mathews for her exceptional work in the editing process.
} 